\title{
Implications of Policies and Procedures in Sustainable Rural Tourism Development (SRTD): A Case Study of Sri Lanka
}

\section{M.S.M. Aslam ${ }^{1 *}$ and Khairil Wahidin Bin Awang ${ }^{2}$}

${ }^{1 *}$. Department of Tourism Management, Sabaragamuwa University of Sri Lanka.aslam@mgt.sab.ac.lk

2. Faculty of Economics and Management, Universiti Putra Malaysia. khairil@upm.edu.my

\begin{abstract}
Developing tourism in rural areas is found as a panacea for many developing countries to alleviate poverty and overcome many other developmental challenges. Although tourism, a non-traditional developmental intervention accrue some economic benefits for local settings, negative impacts of tourism exacerbates the positive impacts. On the one hand Tourism is politically sound development strategy in recapturing and regenerating the development in rural areas on the other hand it challenges the sustainability in the rural development process. This study intended to appraise the role of policies and procedures in Sustainable Rural Tourism Development (SRTD) with the naturalistic evidences from tourism development in rural Sri Lanka. It employed critical qualitative research design to bring forth the interpretations from natural setting through personal interviews, direct observation and field notes in addition to a wide documental review. Documental reviews illuminate a number of ideals of SRTD in supporting local community empowerment, regenerating rural livelihoods, preserving and conserving socio-culture and environment. However, in reality socially constructed world of rural Sri Lanka reveals that the sustainable rural tourism development is curtailed by the inappropriate and unsteady policy formulation and implementation. Weaken policy formulation and implementation in real world of rural tourism development averts the ideals of SRTD.
\end{abstract}

Keywords: local community empowerment, non-traditional livelihood, sustainable tourism ideals, tourism policies

\section{Introduction}

Tourism is one of the largest rapidly growing global industries, underpinned with conquering contemporary socio-economic and environmental challenges. According to the argument of UNCSDNGO Steering Committee (1999) the investors and users are not required to possess awareness necessarily to use natural resources sustainably. Therefore, the industry disrupts preservation and 
conservation of natural and man-made resources to attain business objectives in conjunction with curtailing the sustainability of resources in which tourism has been built, and threaten the survival of present and future generation. Yet, tourism has been recognized as an alternative avenue for rural areas to regain, restore and recapitalize the rural natural and man-made resources, while substituting the widely criticized conventional mass tourism. Different types of tourism and recreation activities have been conceptualized and wrapped up with different labels of alternative tourism, driven into rural areas. Illuminating this Liu (2003) argue that sustainable forms of tourism never reach their objectives through adapting the modern conventional tourism development approaches. The policies and procedures are inevitable element to regulate and operate tourism in rural areas to reach the sustainable development goals.

Policies are found as vital elements in exploring, exhibiting and exploiting of resources. 'Policies are a natural outgrowth of the planning process, as they are a means of achieving the objectives set out in the plans' (Endresen, 1999:16). In general OECD (1993:8) declares that "rural development policy is to improve balance economic opportunities and social conditions between rural and urban areas without destroying the rural heritage and suppressing the market incentives that lead to structural change". According to Roberts and Hall (2001), policies are aimed at securing access to resources and providing opportunities for locals and visitors by means of recreation. Policies also can be a mean to improve the entrepreneur culture and climate particularly for developing skills and capabilities to start and run new businesses in rural areas (Lordkipanidze et al., 2005). However, Jenkins et al., (1998) have identified and developed feasible policies and programmes for addressing rural problems in ways that provide greater self-reliance, more options, and a healthier environment. This is one of the challenges for rural stakeholders. Sharpley (2002) portrays many tourism-policy objectives in rural areas:

I. attracting niche market

II. eradicating seasonality issue and package tourism

III. promoting independent and non-organized tours

IV. inducing socio-economic benefits of tourism for hinterland

V. promoting cultural attractions

VI. substantiating environmentally balanced holidays

In addition, Pearce (2002) suggests encouraging tourism development in rural areas through regional and other policies due to more potentials than other sectors; nevertheless rural conditions are rather unsupportive for the 
development. On one hand rural landscapes demand the tourism inevitably to anticipate the developmental needs pertaining to prevalently available natural and cultural resources. On the other alarming needs of sustainability disapprove the tourism development without policies and procedures.

Special interest and active holiday have turned the rural areas into an important segment of tourism and recreation (Tribe et al., 2000). Lacher and Nepal (2010) comment that the alternative forms of tourism such as ecotourism and rural tourism attract many visitors into rural areas of developing countries. Tourism has started to spread into more remote and peripheral areas over the last few decades progressively and increasing attention has been given to assess the role and impacts of tourism in the development of those areas (Pearce, 2002). Cánoves, et al., (2004) noted that rural tourism development has taken place in different stages, initially as a social function, interlinking families, it was taken as an instrument for regional development, and finally as a product, it was commoditized due to demands from the tourists. Besides, natural and cultural resource endowment, location, competition, entrepreneurial activity, and institutional arrangements differentiate tourism development in rural areas (Gill, 1998). This encourages the industry to expand into more remote areas. This is the resultant of the downturn of rural economies due to struggle to keep pace with and adapt to the vagaries of globalized economy (Hall and Jenkins, 1998). In the 1970s and 80s, the decline in traditional farming agriculture and rapid degradation of natural resources have claimed a shift in the rural economy and led the rural communities to seek non-traditional service oriented economic avenues to sustain rural livelihoods (Fleicher and Pizam, 1997; Sharpley, 2002, 2003; Timothy, 2005; Tribe et al., 2000). For the purpose of subsidizing the traditional livelihood by a non-traditional avenue, tourism has been frequently taken as a complementary tool for economic and social regenerations in rural areas (Briedenhann and Wickens, 2004a; Fleischer and Felsenstein, 2000; MacDonald and Jolliffe, 2003; Okech, 2008). Tourism began to play a significant role in rural development. Sharpley (2002) identifies as an effective catalyst of rural socio-economic development and regeneration. Garrod et al., (2006) magnify tourism as the lynchpin of many rural communities. Müller and Jansson (2007) claim that tourism a development alternative for peripheral areas. In summing up these arguments de Kadt (1979), Pearce (1989) and Lee (2005) state that tourism has long been recognized as a significant avenue to reach development objectives of rural areas.

Although rural development has not been integrated appropriately, previous tourism planning attempts have taken rural development into consideration and emphasized rural-urban balancing through tourism development. Many documents as printed or electronic versions have noted the tourism development in rural areas with different points of view. Herein, Bandara (2003) critiques 
on the integration of rural areas and drawbacks of enclave mass tourism in contributing to rural development in Sri Lanka. In response, Aslam (2011) explicates the role of alternative tourism in rural sustainable development of Sri Lanka, while, Ratnayake and Azilah Kasim (2011) critically analyze the contributions of community tourism to empower rural communities with respect structural limitation. In addition, Wimalaratana and Silva (2009) elucidate the community based tourism as a strategy to improve sustainable development of Monaragala district, which is more remote and a rural district of Sri Lanka. Thus, Green Tech (2010) investigated and identified potential hotspots for nature and bird watching as alternative tourism to enhance the sustainable development in rural areas of the eastern province.

Adding to this, Senanayake and Wimalaratane (2012) extended their case study on agro-tourism and rural development in Sri Lanka with reference to Nuwara Eliya district. Furthermore, Wijewickrma (2011) broadly analyzes agro-tourism industry in Sri Lanka and provides some significant comments to promote and establish agro-tourism at small scale rural farms, and reach international recognition and certification. A qualitative case study of Tisdell and Bandara (2004) in Pinnawela Elephant Orphanage and surrounding explicate the impact of tourism in regional development or rural areas. On the contrary, Simpson (1993) argues on performing culture, traditions and rituals for tourism and commercialization of local socio-culture. However, Fernando and Meedeniya (2009) recognize the changes in recent trend of tourism, which help to reduce the poverty of people through the consumption of cheaper goods and services locally produced.

However, Media Centre for National Development of Sri Lanka (2010) envisages the diversification of tourism into rural development to make village folks as valuable partners in tourism industry and enhance the rural socio-economic development in northwest, north, northeast, east, and north central regions of the country. In addition, International Forum on Community Based Tourism (2011) envisages pushing tourism to new spheres from traditional boundaries in order to benefit the rural communities. In line with this, Sarvodaya (2011) proposes community tourism to empower the rural communities while conserving and preserving the natural and socio-cultural resources

\section{Implication of Policies and Procedures in Rural Tourism Development}

A number of authors such as Page and Getz, (1997), Roberts and Hall, (2001), and Timothy (2005) have argued on the lack of policies and support strategies for rural tourism at higher levels of administration. Testifying this, Fleicher and Felsenstein (2000) state that small scale and family oriented rural tourism industry lead to ignore the policy formulation, even though 
it has significant contributions for rural development. Hall and Jenkins (1998) have noted that more often the tourism industry is concerned with promotion and short-term return than strategic investment and sustainability found along with tourism research and policy making. However, Hall (2007) underlines that tourism to bring contributions to peripheral areas several key policy themes should be better understood. This includes steady changes in response to technological innovations, complex socio-economic and political relationships, and managing social, economic and environmental values. In addition, maintaining intra and intergenerational equity in resource utilization, and maintaining human welfare values should be understood. UNEP (2003) emphasizes on the importance of integrating sustainable tourism policies and priorities with wider local authority policies towards sustainability and vice versa. Government or people in the authority may not produce a document as a policy statement, but their decision making and actions are significantly effective in the implementation of tourism (Richter and Richter, 1985). Policy setting must include the review of goals, nevertheless policy and goal of tourism development in rural areas may not be mutually compatible always (Hall, 2007). Reaching the developmental goals without policy orientation may threaten the sustainability and policy implication without reference to development goals may not allow anticipating the development challenges in the rural landscapes.

A basic issue of policy setting addressed by Pearce (2002) questions, what tourists are in search of? And what attracts them in terms of peripherally? Yet, policy setting for tourism development in rural areas is underpinned with many other issues. Whereas, Hall, (2007) addresses four important issues:

I. Restricted economic policies of many governments have compounded the difficulties of peripheral areas in adjusting to economic and social restructuring.

II. Confrontation of policymakers' inadequate knowledge on peripheral issues and identifying appropriate policy instruments to select, promote and support industries and other productive capacities as viable and sustainable alternatives.

III.Placing higher expectations on tourism as a means of regional development, lead to policy failures.

IV. Lack of prior desires or expectations over the contribution of tourism development and waiting till tourism and visitor growth to result at the end.

In addition, Hall and Jenkins (1998) argue that the pressures of tourism and recreation growth on resource stemming are poorly understood by policy makers for planning, development and management of tourism and recreational 
resource bases. Similarly, land use conflicts of tourism and recreation in rural areas too claims much attention from planners and policymakers (Jenkins and Prin, 1998). While, Jenkins et al., (1998) argue that the formulation and implementation of public policies for rural areas are being challenged by the nature and process of change. Apparently, policy setting and implementation are not given sufficient attention, even though policy can play a crucial role in sustainable tourism development prior to marketing and promotion.

The non-availability of a universally accepted definition for rural areas creates problems when determining policy whether local, state or federal (Long and Lane, 2000). Jenkins et al., (1998) point out that the major struggle among the policymakers is to adopt different policy perspectives on national versus local priorities. And policy setting for rural areas cannot adopt a standard or common policy format for all rural areas, since the rural areas are not uniform and possess various differences in terms of economic base, population dynamics, socio-political networks, and in their inherent natural and human qualities (Ibid). Subsequently, Hall and Jenkins (1998, p.30-32) summarize the major categories and instruments of policy formulation for rural areas as given in the table 2.2 .

Table 02.2: Rural Tourism Development Policy Instruments

\begin{tabular}{|c|c|}
\hline Categories & Instruments \\
\hline Regulatory Instruments & $\begin{array}{l}\text { Laws } \\
\text { Licenses. permits and standard } \\
\text { License, permit } \\
\text { Tradable permits } \\
\text { Quid pro quos }\end{array}$ \\
\hline Voluntary Instruments & $\begin{array}{l}\text { Information } \\
\text { Volunteer association and non-governmental organizations } \\
\text { Technical assistance }\end{array}$ \\
\hline Expenditure & $\begin{array}{l}\text { Expenditure and contracting } \\
\text { Invest or procurements, } \\
\text { Public enterprises } \\
\text { Public private partnership } \\
\text { Monitoring and evaluations } \\
\text { Promotion }\end{array}$ \\
\hline Final Incentives & $\begin{array}{l}\text { Pricing } \\
\text { Tax and charges } \\
\text { Grants \& loans } \\
\text { Subsidize and tax incentives } \\
\text { Rebates, reward and surety bonds } \\
\text { Vouchers }\end{array}$ \\
\hline Non-international & Non-intervention (Deliberate) \\
\hline
\end{tabular}


Hall and Jenkins have attempted to synthesise the different dimensions and aspects of policy setting with respect to governments' role in planning and development process of tourism development in rural areas. However, Hall and Jenkins are concerned only with the government or state appearance in policy setting and other stakeholders such as local community, private entrepreneurs, and Non-Governmental Organizations (NGO) contributions to policy setting are not mentioned apparently.

\section{Methodology}

The study climbed qualitative case study approach, as little is known and previous researches explain about the research phenomena partially or incompletely (Hair et al., 2007). The case study is in holistic-inductive nature and grounding in actuality of applied disciplines such as tourism, policy development and examination (Beeton, 2005). Since "case studies are deliberately designed to answer series of questions" (Yin, 2003:31), vital role of policies and procedures in rural tourism development holistically investigated in the natural setting of rural Sri Lanka to illuminating multiple realities. The study includes the documental review of published and unpublished documents within the premises of the case (Atkinson and Coffey, 2004). It also encompassed interactional empirical data collection (Holstein and Gubrium, 1997) from different stakeholders such as semi-structured interview of authorities and operators to elicit in-depth information and plural meaning (Yin, 2009), and direct observation of communities and operators to collect first hand data from social world while cross-checking the data obtained from other means (Tjora, 2006). In addition, investigation was supported by focus group discussions of some local stakeholders. The empirical investigations has been carried out from November 2012 till April 2014 in 8 provinces of Sri Lanka excluding Northern Province and a part of eastern province, which were fully affected by war. Semi structured interviews were carried out with national, provincial and local level authorities, who have carried out tourism development activities in rural Sri Lanka. Direct observation and focus group discussions also carried out in rural areas, where any sort of tourism development activities had taken place. Empirical investigation also included semi structured interview of private tourism developers and operators in rural Sri Lanka. The researcher had to carry out $t$ the empirical investigations in rural Sri Lanka till reached the point of saturation. The factual interpretations are triangulated and analysed descriptively in order to embark the empirical realities. 


\section{Result and Discussion}

Policy setting or formulation is a challengeable task that determines the success of the entire rural tourism development process. Research of Christine et al., (2015) in the three newly developed tourism zones, Kalpitiya, Kuchaveli and Passikudah, illustrates detrimental outcomes of tourism development in rural areas without policies and procedures.

"The livelihood of fishermen and their families is seriously threatened. In the new tourism zones, land is grabbed and the residents are resettled, more often than not with insufficient warning or compensation. Only a few people in the environment of the new tourism resorts are able to make a living from the emergent tourism. The majority of hotel employees are recruited from other Sri Lankan regions and local fishermen are hardly ever chosen as suppliers for the hotels." (Christine et al., 2015:1).

Booming tourism development in the country leads to further deprivation of the rural community rather than supporting for their empowerment. Augustyn (1998) notes that the stimulating role of rural tourism in rural development claims priority in national policy setting. Managing resources in rural tourism development process determine the sustainability. Thus, a tourism policy is an indispensable precursor in tourism planning and development as it provides a framework for strategic planning (Nzama, 2010). Wood (2004a:9) states 'it is difficult to imagine progress toward sustainable tourism unless important regulatory and policy gaps are addressed'. Briedenhann (2008) argues on the importance of the public sector involvement in rural tourism policy and plans formulation. Augustyn's (1998) study in Poland elucidates that the national policy on sustainable rural tourism development helped to attain quantitative goals and fails to reach the qualitative goals. In the investigation of the national level policy formulation for the rural tourism development in Sri Lanka, Interviewee 1\# (personal communication, 2012) described;

"It is not like that, we have a corporate plan, it is the map of the three year development plan, and with that corporate plan all these projects are linked. Second thing, in new tourism map they have said that we should have five year plan and it should be approved by the cabinet of ministers. Four year plan not a five year plan".

This implies that policy formulation for rural tourism development is not recognized at national level tourism planning. Revealing this Interviewee 2\#, Director General, North-Western Province (NWP) Development Authority (personal communication, 2012) stated "we have not identified national policies other than, what has been identified in the Mahinda Chinthana". Interviewee 3\# (personal communication, 2013) informed that in Sri Lanka there is no policy for anything. His facial expression conveyed his unhappiness 
and frustration on the policy formulation and implementation in Sri Lanka. Yet, rural tourism policy and planning interweaves diverse public sectors due to the fragmented nature of tourism (Briedenhann, 2008; Church et al., 2000). When inquiring about policy formulation at provincial level, Interviewee 4\# (personal communication, 2012) verbalized;

"When we take Sri Lanka, after ending of the war, a plan developed for Sri Lanka, "Future Vision, Mahinda Chinthana". With this the most suitable potential to develop village is tourism. Even in the Mahinda Chinthana there is a plan for sustainable tourism. With reference to this only we develop the plan for the central province with the support of Sabaragamuwa University of Sri Lanka. This will focus on village (rural) development. Provincial policy for the Central Province is also being developed".

Accepting 'Mahinda Chinthana' as the policy document is a very common fact in all public institutions. It is only a developmental forecast of the country and does not provide policy guidelines for the rural tourism development. In interpreting the role of the REDA in policy formulation, Interviewee 5\# (personal communication, 2012) stated "when initiating a project, at the beginning we mediate and try to prepare these documents. But in Heeloya programme it was done by the ICEI/OVERSEAS, they also followed the same way". He also pointed out that rural people will prepare the policy document naturally when the need arise, and pushing before that may create conflict between the authority and the community. In the North-Central province, Development Assistant, Interviewee 6\# (personal communication, 2012) expressed "we educate them about the policies, just they cannot get involve in tourism, there, we discuss about this with them". She only meant that they educate rural people about policy formulation, but they could not produce any formulated policy for rural tourism.

However, I could review some policies in Sabaragamuwa Province Tourism Master Plan for 2009 -2014 that generally encompasses tourism planning and development for the rural spheres in Sabaragamuwa province (Sabargamuwa Tourism Development Plan, 2010). Yet, the Secretary, Ministry of Tourism Sabaragamuwa, could not mention anything clearly during the personal communication. Interviewee 7\#, Ministry of Tourism, Uva province (personal communication) informed that it does not contain any policy framework, but there are guidelines, the document should be taken as a methodology. He interpreted this as a policy and should be adapted for long term tourism development'. The factual information brings meanings that PTAs also do not pay attention on policy formulation and implementation. Yet, the development of rural tourism has become a major element of rural and regional development policies in the EU. And, nowadays, this is one of the most important strategies for the diversification of economic activities in lagging and remote rural areas (Briedenhann and Wickens, 2004; Clarke et al., 2001; Fleischer and 
Felsenstein, 2000; Skuras et al., 2006; Wanhill, 1997). Negligence of policy formulation could be confirmed further at local government level. Interviewee 8\#, PS Gribawa (Hasthi Kuchchi) stated "no, there is no anything (policy documents) such. Why, we don't much consider or value the tourist visits to this place" (personal communication, 2012). This leads to encapsulate no public agencies' interest on policy formulation for rural tourism development.

Investigation on policy formulation at rural tourism initiatives in rural Sri Lanka also did not derive any meaning on the policy formulation. Most of the respondents' interpretations were negative and unclear. For example, the CBTO president at Heeloya mentioned "yes, so far we haven't come across a situation, but in future we may need to provide a procedure for that. If they visit the village with short dresses, we don't have dresses to offer them" (Heeloya focus group discussion, 2013). Interviewee 9\# at Bohmure stated "we can't enforce rules and regulations for the tourists, who come for independent enjoyment. We should allow them free from restriction and barriers". Interviewee 10\#, Operator of Lake and Village Adventure Tour (personal communication, 2012) verbalized "yes, we do the tour very calmly and quietly without disturbing the environment and society, I have asked them to take care of guest and guide safety, now they ride boat, which is combined with two boats. We have asked the villagers to keep the place very clean". These interpretations do not make any sense about the policy formulation. However, during my interactions I could notice that either the authority people or the NGO representatives try to make aware the rural people and bring forth some meanings from them. For an instance, Interviewee $11 \#$ tries to educate the Seelogama CBTO members as;

"We should have the policy on how to operate this programme; this should not be changed person to person. As soon as you try to change, problems arise. We should clearly state that we provide these at these prices and these conditions. If operate like this with appropriate policies without any person orientation, we will be able to carry on this programme without any problems. We should not much linear or flexible to change the system for individual expectation, then individual conflicts and problems may arise".

Rural people also show the interest to learn and formulate policies for the rural tourism development. Interviewee 9\# (personal communication, 2013) said "those things will be very good and compulsory for the future of the village. Similarly, tourists should be allowed to stay at authorized places only". A CBTO activist at Padavigampola mentioned "we understand the need for it and we want it, but due to the delay in functioning didn't raise the issue much and lack of experience also one of the reasons for that". People accept the importance of policies and procedures but they are reluctant for 
implementation (Bandara, 2009). However, in a few rural tourism initiatives such as Walawa Nadee Ecotourism, Rekawa Community Tourism initiatives hold some operational level policies to safeguard tourists, hosts and the environment.

Another prevalent and serious shortcoming is the absence of stakeholder integration and collaboration in policy formulation. Department of Tourism, South Africa (2012) proposes integrated governance that refers to an "approach in governance" which involves integrated policy development; integrated strategic planning; integrated budgeting; as well as integrated implementation strategies, monitoring and evaluation. Bramwell and Sharman (1999:394) suggest "communicative" approaches in planning that enables relevant stakeholders to have a voice in policymaking. The conflicts and disputes among the community, tour operators and the government elucidate the consequences of disintegrate and uncooperative policy formulation and implementation. Interpreting this Interviewee 3\# (personal communication, 2013) "there are places with restricted policies, but there is a big gap between these policies and national policies. So how can we use these policies to common places such as Sigiriya, Sinharaja? There we need national policies". In addition, Interviewee 12\# (personal communication, 2013) conveyed his disagreement and disappointment by pointing out many constraints in policy formulation, dissemination and implementation. The overall naturalistic description enable me to interpret that rural tourism policy formulation has not reached the interest of stakeholders, specially public agencies' since they are prime responsible people for policy formulation and implementation. Poor capacity of rural communities doesn't allow understanding and involving in policy formulation. Moreover, lack in integration and cooperation leads to poor policy formulation and implementation in rural areas to ensure the sustainability.

Attaining the goals and objectives of sustainable rural tourism development depends on the implementation of the policy and procedures. Cawley and Gillmor (2008) argue that inappropriately regulated rural tourism can engender the threats for the quality of physical environments and socio-culture. A tourism policy draws the developmental parameters from the availability of resources, the nature of the tourism products, marketing, envisaged target markets, outlined alternatives, choices, strategies and plans (Nzama, 2010). When conversing about the impacts of policy implementation Interviewee $3 \#$ (personal communication, 2013) pointed out "development journey without policies can be a national disaster". In verifying the consequences of the poor policy support Interviewee 2\# (personal communication, 2012) stated "in NWP new tourism entrepreneurs are coming up, organizations are coming up, new venture are coming up these don't generate any income for us, no five cents of income from these. This is a problem of the constitution". Yet, 
Skuras et al., (2006) state that due to strong policy support, large amounts of public money are being spent today on the development of tourism in the remote and less developed regions of the EU. Implementation of policies provides assurance for the investment and fair distribution of benefits among the stakeholders, while negligence in policy implementation ruins the trust on investment and infringes the equity in benefit sharing.

Policy implementation support is not only an economic dimension but also in socio-culture and environmental dimensions. Elucidating the impact of policy application, Interviewee 13\#, president of CBTO at Heeloya (Heeloya focus group discussion, 2013) recalled "when two female tourists went to see the farm and one of them tried to smoke, the other one instructed not to do that. Tourist, by themselves tried to protect the law and order. Afterwards we realized the importance having policies in writing". Clear policy implementation has a significant impact in safeguarding local socioculture. Interviewee 3\# (personal communication, 2013) portrays the impacts of policy implementation at Hikkaduwa, another popular beach tourist resort area as follow;

"We have one such policy initiative in Hikkaduwa. When we could notice the destruction of corals due to boat riding over that, we negotiated with wildlife established certain rules and regulations. We listed only 85 boats are allowed with low engine, 5 horse power, now it is implemented, the efforts took implement that are very complicated. Earlier, one boat owner had 3 or 4 boats and sent his guides, wearing only shorts and pulling the tourists by force. See how much ugly this, not only that pulling the tourists by force and charging as they wish, there is equal rate, if he think Rs. 30,000, he charge that. Now wild life issue the tickets, there is an agreed rate, eight boats only at a time, there a riding limit, earlier they were dominating whole place, they have to put wiper glass, snorkelling tourists should be safe guarded".

The rural policies concentrated tourist activity into key geographic areas leading to problems of misuse, erosion, bad design and lack of visitor management (Church et al., 2000). Policy implementation strengthens preservation and conservation of natural and human resources through tourism. Verifying this, indigenous tourism policies in Australia enabled indigenous people to involve in land and natural resource management and sustainable tourism while building partnership with non-indigenous groups and mainstream tourism agencies (Whitford and Ruhanen, 2010). Revealing the impact of policy implementation on authenticity and quality of tourism, Interviewee 14\# (personal communication, 2013) spelled out "otherwise in the areas there can be people, if I say the price, they can offer a cheap price and cheat tourists to earn money". Implementing policies in rural tourism development helps to guarantee the genuinely and quality of rural tourism for optimum satisfaction 
of tourists. Bandara (2009) also elucidates that ecotourism practices failed to yield sustainable results due to poor policy integration and implementation in Sri Lanka.

The interactions in natural rural settings make out that implementation of policies engender further conflicts and disputes among the stakeholders. When authorities intervene to implement the policy in coastal areas to push the physical development $500 \mathrm{~m}$ from coast towards inland, conflicts and disputes arose between community, tourism service providers and authorities. Testifying this at Arugam Bay and Unawatuna, people and service providers showed their antagonism and resistance for the government intervention, even though policy implementation would benefit rural tourism development potentially. Interviewee 12\#, a diving operator (personal communication, 2013) explained;

"Then, we faced a very unfair situation. Now this place is mine, how can I push this beyond $500 \mathrm{~m}$, is that land behind this belonging to me? No. Not only for me but also for everybody has to face this situation. Now person, who operate diving, should be in the beach, it is also no problem, if this area is clear. It won't be practical any 500m up to here".

Similarly at Arugam Bay, tourist facilities are provided in a highly congested environment with minimum basic facilities very nearby the beach. Yet, people are reluctant to change established places of their livelihood or stop further physical development at those places. The observation verified that people misinterpret the policy implementation and impacts as negative outcomes. This can be the result of poor rural capacity and absence of cooperative planning and decision making in rural tourism development. Absence of policies and procedures devastates the sustainable rural tourism development. Appropriate policy implementation can generate many positive impacts on socio-economy and the environment of rural destinations while providing genuine and quality tourism and recreation activities. However, impacts of policy implementation can be further conflicting and disputing due to poor capacity and lack of cooperative planning and development.

\section{Conclusion}

Global tourist arrival 25 million in 1950s reaching nearly 1 billion in 2000s remarks a surprising growth of tourism. Increased tourist arrivals not only widen the spectrum of recreation but also generate and expanded the source of livelihood for a wide array of people and nations either developed or developing. Unexceptionally, rural areas also encountered the tourism as an ideal development tool to regenerate rural economy and socio-culture during post Second World War II. Yet, fragile and fragmented nature of rural 
socio-cultural and natural resources disapprove any unsustainable tourism developmental intervention. This emphasizes the integration of policies and procedures in tourism development to safeguard the sustainability. Inclusion of rural tourism policies at different dimensional and sectoral planning is primary requirement of sustainable rural development. Appropriate policy setting and implementation is a commonly agreed criterion to ensure the sustainability. This benefits the socio-cultural, environmental and economic sustainability through various corners of tourism operation. However, tourism development in Sri Lanka has failed to ensure the rural community empowerment. This has led to loss of traditional livelihoods, increase in youth migration, degradation local socio-culture and environment and evacuation of community from native places. Naturalist interpretations and in-depth investigations in the rural setting reveal that tourism developments are carried out in rural landscapes of Sri Lanka in the absence of appropriate policy setting and implementation. This elucidates a number of issues: poor recognition and awareness on the importance of policies and procedures; poor collaboration and integration of stakeholders and different sectors in policy setting and implementation; communities' aspirations and their empowerment have been overlooked; contradiction between policies and development goals; late policy implementation after the development causes disputes and conflict between authorities and developers. Reaching sustainable rural developmental goal through tourism is possible only when timely and appropriate policies are formulated and implemented in collaboration with all stakeholders while considering the development goals, communities' aspiration and their empowerment.

\section{References}

Aslam, M.S.M. (2011). Role of Alternative Tourism in Rural Sustainable Development, Economic Review, 36 (11 and 12): 33-38.

Atkinson, P. and Coffey, A. (2004). Analysing Documentary Realities, in Qualitative Research: Theories, Methods and Practice, 2nd Edn. ed. D. Silvermann pp. 56-75, London: SAGE Publications.

Augustyn, M. (1998). National Strategies for Rural Tourism Development and Sustainability: The Polish Experience, Journal of Sustainable Tourism, 6(3): 191-209.

Bandara, H.M. (2003). Tourism Planning in Sri Lanka, Colombo: Stamford Lake.

Bandara, R. (2009). The Practice of Ecotourism in Sri Lanka: An Assessment of Operator Compliance towards International Ecotourism Guidelines, South Asia Economic Journal, 10: 471-492. 
Beeton, S. (2005). The Case Study in Tourism Resarch: A Multi-method Case Study Approach, in Tourism Research Method: Integrating Theory with Practice, eds. B.W. Ritchie, P.Burns and C. Palmer, pp. 37-48, Wallingford: CAB International.

Bramwell, B. and Sharman, A. (1999) Collaboration in Local Tourism Policy Making, Annals of Tourism Research, 26(2): 392-415.

Briedenhann J. (2008). The Role of the Public Sector in Rural Tourism: Respondents' Views, Current Issues in Tourism, 10(6): 584-607.

Briedenhann J. and Wickens E. (2004). Tourism Routes as a Tool for the Economic Development of Rural Areas_-Vibrant Hope or Impossible Dream? Tourism Management, 25(1): 71-79.

Cánoves, G., Villarino, M., Priestley G. K. and Blanco, A. (2004). Rural tourism in Spain: an analysis of recent evolution, Geoforum, 35: 755-769.

Cawley, M. and Gillmor, D. (2008). Integrated Rural Tourism: Concepts and Practices, Annals of Tourism Research, 35(2): 316-337.

Church, A., Ball, R., Bull, C. and Tyler, D. (2000). Public policy engagement with British tourism: The national, local and the European Union, Tourism Geographies: An International Journal of Tourism Space, Place and Environment, 2(3): 312-336.

Clarke, J. Denman, R. and Hickman, G. (2001). Rural tourism in Roznava Okres: a Slovak Case Study, Tourism Management 22: 193-202.

de Kadt, E. (Ed.) (1979). Tourism: Passport to Development? New York: Oxford University Press.

Department of Tourism - South Africa, (2012). Rural Tourism Strategy: April/2012, Department of Tourism, South Africa, www.tourism.gov.za/.../ National\%20Rural\%20Tourism\%20Strategy.pdf Retrieved on September 10, 2013.

Endresen, K., (1999). Sustainable Tourism and Cultural Heritage: A Review of Development Assistance and its Potential to Promote Sustainability, NWHO: Norway, http://www.nwhf.no/files /File /culture_fulltext.pdf, Retrieved on January 24, 2012

Fernando, K. \& Meedeniya, A. (2009). Recent changes in tourism trends in Sri Lanka and implications for poverty reduction, Centre for Poverty Analysis, Colombo: Asian Development Bank. 
Fleischer, A. and Felsenstein, D., (2000). Support for Rural Tourism: Does it make a difference? Annals of Tourism Research, 27: 1007-1024.

Fleischer, A. and Pizam, A. (1997). Rural tourism in Israel. Tourism Management, 18(6): 367-372.

Garrod, B., Wornell, R. and Youell, R. (2006). Re-conceptualising Rural Resources as Countryside Capital: The Case of Rural Tourism, Journal of Rural Studies, 22: 117-128.

Gill, A. (1998). Local and Resort Development.In Tourism and Recreation in Rural Areas, R.Butler, C.M. Hall, J.M. Jenkins, Eds., pp. 96-111, Chichester: Wiley.

Green Tech (2010). An Assessment of the Potentials and Current Constraints for the Promotion of 'Bird Watching' Nature Tourism in Eastern Province, Final Report, September 1, 2010, North East Coastal Community Development Project (NECCDEP), Colombo: Green Tech.

Hair, J.F., Money, A.H., Samouel, P. and Page, M. (2007). Research Methods for Business, England: John Wiley \& Sons Ltd.

Hall, C.M. (2007). North-South Perspectives on Tourism, Regional Development and Peripheral Areas.In Tourism in Peripheries: Perspectives from the Far North and South, Eds. D.K. Müller, and B. Jansson, pp. 19-37, Wallingford: CAB International.

Hall, C.M. and Jenkins, J.M. (1998), The Policy Dimensions of Rural Tourism and Recreation, in Tourism and Recreation in Rural Areas Eds. R. Butler, C.M. Hall, J.M. Jenkins, pp. 19-42, Chichester: Wiley.

Holstein, J.A. and Gubrium J.A. (1997). Active Interviewing. In Qualitative Research: Theory, Method and Practice, Ed. D. Silverman, pp. 113-129, London: SAGE Publication.

Int'1 Forum on Community Based Tourism Today. from http://print2. dailymirror.1k/ business/127-local/58172-intl-forum-on-community-basedtourism-today-.html, Daily Mirror, 2011. Retrieved on November 14, 2012.

Jenkins, J.M. and Prin, E., (1998). Rural Landholder Attitudes: the Case of Public Recreational Access to Private Rural Lands.In Tourism and Recreation in Rural Areas, Ed. R. Butler, C.M. Hall and J.M. Jenkins, pp. 179-196, Chichester: Wiley. 
Jenkins, J.M., Hall, C.M. and Troughton, M. (1998). The Restructuring of Rural Economies: Rural Tourism and Recreation as a Government Response. In Tourism and Recreation in Rural Areas, R. Butler, C.M. Hall, J.M. Jenkins, ed. pp. 19-42, Chichester: Wiley.

Lacher, R.G. and Nepal, S.K., (2010). From Leakages to Linkages: LocalLevel Strategies for Capturing Tourism Revenue in Northern Thailand, Tourism Geographies, 12(1): 77-99.

Lee, M.H., (2005). Farm Tourism Cooperation in Taiwan, in Rural Tourism and Sustainable Business, D. Hall, I. Kirkpatrick, and M. Mitchell, Eds., pp: 201-224, Channel View Publications: Great Britain.

Liu, Z. (2003). Sustainable Tourism Development: a Critique, Journal of Sustainable Tourism, 11(6): 459-475.

Long, P. and Lane, B., (2000). Rural Tourism Development, in Trends in Outdoor Recreation, Leisure and Tourism, Eds. W.C. Gartner and B.W. Lime, pp. 299-308, Wallingford: CAB International.

Lordkipanidze, M., Brezet, H., and Backman, M. (2004), The Entrepreneurship Factor in Sustainable Tourism development, Journal of Cleaner Production, 13(8): 787 -798.

MacDonald, R., and Jolliffe, L. (2003). Cultural Rural Tourism, Evidence from Canada, Annals of Tourism Research, 30(2): 307-322.

Media Centre for National Development of Sri Lanka (2010). Tourism Diversified to Rural Development, Ministry of Mass Media and Information Sri Lanka, http://www.development.lk/news.php?news=283. Retrieved on October 25, 2012.

Müller, D.K., and Jansson, B. (2007). The Difficult Business of making Pleasure Peripheries Prosperous: Perspectives on Space, Place and Environment, in Tourism in Peripheries: Perspective From Far North and South, D.K. Müller and B. Jansson Eds., pp. 3-18, Wallingford: CAB International.

Nzama, T.A. (2010) Challenges of sustainable rural tourism development in KwaZulu-Natal, www.ajol.info/index.php/ijhss/articlel download/62121/50159. (Retrieved on September 10, 2013)

OECD. (1993). What Future for Our Countryside? A Rural Development Policy, Paris: OECD.

Okech, R.N. (2008). Promoting Rural Tourism in Kenya and Romania, The Annals of The "Stefan cel Mare" University Suceava, 8(8): 22-28. 
Paje, S. J., and Getz, D. (1997). The Business of Rural Tourism: International Perspectives, London: International Thomson Business Press.

Pearce, D. (1989). Tourism Development 2nd edn, Harlow: London.

Pearce, D.G. (2002). Tourism and Peripherality: Perspectives from Asia and the South Pacific, Tourism and Hospitality Research, 3 (4): 295-309.

Plüss, C., Sahdeva, N. and Monshausen A. (2015) Tourism in Sri Lanka: Human Rights Due Diligence of Tour Operators in Post-Conflict Areas, arbeitskreis tourismus \& entwicklung (Working Group on Tourism and Development); Tourism Watch: Berlin.

Roberts, L. and Hall, D. Eds. (2001). Rural Tourism and Recreation: Principles to Practice, Wallingford: CAB International.

Sabaragamuwa Tourism Development Plan, 2010, Ministry of Rural Infrastructure, Roads and Tourism Development, Ratnapura: Sabaragamuwa Provincial Council.

Sarvodaya, (2011). What is Community Tourism. http:/www.sarvodaya. org/ activities/community-tourism/what-is-community-tourism. Retrieved on November 2, 2011.

Senanayake, S.M.P and Wimalaratana, W. (2012) Agro Tourism and Rural Development in Sri Lanka, With Special Reference to Nuwara Eliya District, Colombo: University of Colombo, http://archive.cmb.ac.lk:8080/research/ handle/ 70130/1834. Retrieved on October 20, 2012.

Sharpley, R. (2002). Rural tourism and the challenge of tourism diversification : the case of Cyprus, Tourism Management, 23: 233-244.

Sharpley, R. (2003). Tourism, Modernization and Development on the Island of Cyprus: Challenges and Policy Reponses. Journal of Sustainable Tourism, 11(2\&3): 246-265.

Simpson, B. (1993). Tourism and Tradition: from Healing to Heritage, Annals of Tourism Research, 20: 164-181.

Skuras, D., Petrou, A. and Clark, G. (2006). Demand for Rural Tourism: the Effects of Quality and Information, Agricultural Economics, 35: 183-192.

Timothy, D.J, (2005). Rural Tourism Business: A North American Overview, in Rural Tourism and Sustainable Business, Eds. D. Hall, I. Kirkpatrick and M. Mitchell, pp: 41-62, Bristol: Channel View Publications. 
Tisdell, C. and Bandara, R. (2004) Tourism as a Contributor to Development in Sri Lanka: An Overview and a Case Study, Working Paper No. 94, http:// ageconsearch.umn.edu/bitstream/48975/2/WP94.pdf, Retrieved on October 20,2012

Tjora, A.H. (2006). Writing small discoveries: an exploration of fresh observers' observation, Qualitative Research 6(4): 429-451.

Tribe, J., Font, X., Griffiths, N., Vickery, R. and Yale, K. (2000). Environmental Management for Rural Tourism and Recreation, London: Cassell.

UNCSD NGO Steering Committee, (1999). Sustainable Tourism: A NonGovernmental Organization Perspective in Tourism and Sustainable Development, Department of Economic and Social Affairs, New York: United Nation.

UNEP, (2003), Tourism and Local Agenda: The Role of Local Authorities in Sustainable Tourism, UNEP: Paris, http://www.unep.fr/shared/publications / pdf/3207, TourismAgenda.pdf. Retrieved on March 10, 2012.

Wanhill, S. (1997). Peripheral Area Tourism-European Perspectives. Tourism and Hospitality Research, 3: 47-70.

Whitford, M.M. and Ruhanen, L.M. (2010).Australian indigenous tourism policy: practical and sustainable policies?, Journal of Sustainable Tourism, 18(4): 475-496.

Wijewickrama, B.E.N. (2011). Sri Lanka's Agro-Tourism Industry: The Demand and Current Practices, Posted on November 10, 2011 by 08/ASB/185 http://www.sci.sjp.ac.lk/lms/wordpress/?p=457, Retrieved on October 20,2012

Wimalaratana, W and Silva, D.A.C. (2009). Community Based Sustainable Tourism: A Case Study of Monaragala District, Sri Lanka Journal Agrarian Studies, 13(1), http://archive.cmb.ac.lk:8080/research/ handle/ 70130/1834. Retrieved on October 20, 2012

WOOD, E.M. (2004a), 'An Ecotourism Project Analysis and Evaluation from Work for International Development Donors: Defining Indicators for Conservation, Community and Local Enterprise Development', Conference on Ecotourism and Conservation in Americas, Stanford University, USA.

Yin, R.K (2009), Case Study Research: Design and Methods, 4thEd. Lexington, USA 
Yin, R.K. (2003). Application of Case Study Research $2^{\text {nd }}$ Edn, Thousand Oaks: Sage Publication, Inc. 